УДК $78.03+785.7$

DOI https://doi.org/10.31723/2524-0447-2020-31-2-5

Людмила Олександрівна Снєгірьова

ORCID: 0000-0002-7221-0440

в. о. доцента кафедри концертмейстерства

Одеської національної музичної академії імені А. В. Нежданової odma_n@ukr.net

\title{
СТИЛІСТИКА КАМЕРНО-ВОКАЛЬНИХ ТВОРІВ В. КОСЕНКА: ДО ПИТАННЯ ІНДИВІДУАЛЬНО- КОМПОЗИТОРСЬКОЇ ТРАКТОВКИ ЖАНРОВОЇ ТРАДИЦІЇ
}

Мета статmі полягає у визначенні особливостей стилістики камерно-вокальних творів В. Косенка, які комплексно утворюють специфіку індивідуально-авторського трактування цієї жсанрової традииії. Методологія дослідження. Методологічною основою дослідження $\epsilon$ системний метод, що дає змогу розглядати окремі елементи стилістики романсів українського композитора як складники иілісного явища індивідуального композиторського стилю і його прояву в інтерпретації жанрової традиції, а також музикознавчий метод жсанрово-стильового аналізу, який спрямований на виявлення стилістичного комплексу творів В. Косенка. Також використовується біографічний метод, який дає змогу співвідносити особливості творчої біографії композитора з індивідуальним стильовим виглядом його камерно-вокальної лірики. Наукова новизна статті визначається теоретичною розробкою камерно-вокальної спадщини В. Косенка в аспекті специфіки індивідуально-композиторського стилю, який утворює ключову рушійну силу в історичній динаміці жанрової традиції. Зазначений аспект значною мірою заповнює «загальний» погляд на вокальну лірику видатного українського Майстра малих форм, що переважає в вітчизняних музикознавчих дослідженнях. Висновки. Стилістика романсів В. Косенка вибудовується за принципом успадкування $і$ творчої інтерпретації класичних жанрових канонів європейської камерно-вокальної лірики. Індивідуально-композиторське трактування жанрової традиції пов'язане переважно з ідеєю збагачення "романтичного духу» малої вокальної форми мелодійною виразністю, властивою українському солоспіву. Також суттєвою для В. Косенка виявляється спадкоємність від традицій російської камерно-вокальної лірики, зокрема від стилістики романсів C. Рахманінова, яка надає творам українського композитора традиціоналистські стильові характеристики. Це дає змогу розглядати камерно-вокальну спадщину В. Косенка та індивідуально-стильові орієнтири

(C) Снєгірьова Л. О., 2020 
українського композитора як їхню «охоронну» функцію, що спрямована на збереження $i$ зміцнення базових жсанрових приниипів $i$ жанрового стилю камерно-вокальної лірики в умовах активного поновлення музично-естетичних канонів на межі XIX-XX cm.

Ключові слова: жанрова традиція, камерно-вокальна лірика, камерний стиль, стилістика, індивідуально-композиторський стиль.

Sniehirova Liudmyla Oleksandrivna, Associate Professor at the Department of Accompaniment of the Odessa National A. V. Nezhdanova Academy of Music

The stylistics of chamber-vocal works by $V$. Kosenko: on the issue of individual composer interpretation of genre tradition

Research objective is to determine the stylistic features of chamber-vocal works by $V$. Kosenko, which comprehensively form the specifics of the individual author's interpretation of this genre tradition. The methodology of the research is: a systematic method that allows you to consider individual elements of the style of the romances of the Ukrainian composer as components of the holistic phenomenon of the individual composer's style and its manifestation in the interpretation of the genre tradition; musicological method of genrestyle analysis, which is aimed at identifying the stylistic complex of works by $V$. Kosenko; a biographical method that allows you to correlate the features of the composer's creative biography with the individual stylistic appearance of his chamber-vocal lyrics. The scientific novelty of the article is determined by the theoretical development of $V$. Kosenko's chamber-vocal heritage in terms of the specifics of the individual composition style, which forms a key driving force in the historical dynamics of the genre tradition. This aspect to a large extent compensates for the prevailing "general" look at the vocal lyrics of the outstanding Ukrainian master of small forms, prevailing in domestic musicology research. Conclusions. The stylistics of $V$. Kosenko's romances is built on the principle of inheritance and creative interpretation of the classic genre canons of European chamber-vocal lyrics. The individual composer interpretation of the genre tradition is mainly associated with the idea of enriching the "romantic spirit" of a small vocal form with the melodic expressiveness inherent in the Ukrainian solospeiv. Also significant for $V$. Kosenko is the continuity from the traditions of Russian chamber-vocal lyrics, in particular from the style of $S$. Rachmaninov's romances, which gives the works of the Ukrainian composer traditionalist style characteristics. This allows us to consider the chamber-vocal heritage of $V$. Kosenko and the individual style guidelines of the Ukrainian composer as their "guardian" function, aimed at preserving and strengthening the basic genre principles and genre style of chamber-vocal lyrics in the context of the active updating of musical and aesthetic canons at the turn XIX-XX centuries.

Key words: genre tradition, chamber-vocal lyrics, chamber style, stylistics, individual composer style. 
Актуальність теми дослідження. Творча постать Віктора Косенка займає значне місце у просторі українського музичного мистецтва XX ст., ліричний склад його світосприйняття та музичного мислення зумовили жанрові пріоритети творчого доробку композитора, які пов'язані з камерною музикою. Камерно-вокальні твори поряд із фортепіанними опусами займають у цьому сенсі центральне місце і виступають яскравим репрезентантом індивідуально-композиторського стилю українського митця. Звертаючись до малих форм романсу та пісні, В. Косенко виступає видатним інтерпретатором європейської традиції камерно-вокального жанру, для якої першорядним питанням завжди було розуміння природи вокально-інструментального ансамблю як основного чинника художньої цілісності твору та його стилістичних параметрів. Тому розгляд зразків камерно-вокальної музики В. Косенка саме в цьому аспекті дає змогу визначити авторський погляд композитора на діалогічне співвідношення вокальної та фортепіанної партій в контексті жанрової традиції.

Мета дослідження - визначити особливості стилістики камерно-вокальних творів В. Косенка, які комплексно утворюють специфіку індивідуально-авторського трактування цієї жанрової традиції.

Наукова новизна статті визначається теоретичною розробкою камерно-вокальної спадщини В. Косенка в аспекті специфіки індивідуально-композиторського стилю, який утворює ключову рушійну силу в історичній динаміці жанрової традиції. Зазначений аспект значною мірою заповнює «загальний» погляд на вокальну лірику видатного українського Майстра малих форм, що переважає у вітчизняних музикознавчих дослідженнях.

Виклад основного матеріалу. Загальна проблематика камерної творчості В. Косенка досліджувалася О. Олійник, Р. Стецюком, М. Ржевською, Т. Менцінським, Л. Свірідовською; різні аспекти камерно-вокальної спадщини композитора розглядалися в публікаціях Б. Фільц, М. Грінченка, Т. Булат, Ю. Малишева, В. Антонюк, I. Вавренчука, О. Тюріної, О. Жукової та ін. Питання індивідуально-композиторського трактування жанрових традицій камерно-вокальної лірики в названих працях спеціально не порушувалися, спадщина видатного українського композитора розглядалася переважно в загальному контексті розвитку українського музич- 
ного мистецтва першої половини XX століття. Як відомо, сам В. Косенко зазначав особливе значення психологізму для своєї творчості, який він відчував як вихідний імпульс творчого процесу: «відчуваю свою музику як продукт душевних переживань, а не зовнішньої мішури» [6, с. 84]. Цей вислів композитора згадується майже всіма дослідниками його музичної спадщини і виступає як основний критерій оцінки ліричної природи таланту В. Косенка і жанрових пріоритетів його творчості, пов'язаних із малими формами інструментальної та вокальної музики. Дійсно, В. Косенко увійшов в історію української музичної культури як видатний майстер малих форм, в яких зумів на найвищому художньому рівні зафіксувати різноманітний світ людських емоцій і почуттів, це надає його музиці особливий лірико-сповідальний тон, що йде від традицій музичного романтизму.

Шодо жанрової традиції камерно-вокального мистецтва це особливо важливо, оскільки саме в творчості композиторів-романтиків склався класичний стиль вокальної мініатюри як самостійного жанрового феномена, який виступив яскравим репрезентантом того стильового канону камерної музики, що принципово відрізняється від естетики «великих» кантатно-ораторіальних жанрів. А. Сохор, говорячи про цю відмінність, виділяє такі стильові риси камерності, як «переважаючий інтерес до особистісного, приватного, тяжіння до деталізації тощо» [7, с. 136], і далі зазначає, що «...ці відмінності, які можна назвати жанровим змістом і жанровим стилем камерної музики, зумовлені невеликою кількістю виконавців i, внаслідок цього, порівняно обмеженою кількістю аудиторії» [7, c. 136-137].

Новий етап розвитку жанрової традиції камерно-вокального мистецтва припадає на рубіж XIX-XX ст., коли світоглядні суперечності перехідної епохи особливо гостро зазвучали в неоромантичній та символістській поезії: нова художня образність і філософська глибина поетичної творчості виступила природним і закономірним стимулом музичного втілення тем і образів, пов'язаних із внутрішньою стороною людського існування і безмежним світом потаємних почуттів. Цей історичний етап став дуже важливим для української композиторської школи на шляху розвитку камерно-вокального мистецтва, оскільки саме від того часу формувалася національна традиція «малих» вокальних форм у творчості М. Лисенка та 
видатних представників XX століття - В. Косенка, М. Вериківського, Я. Степового, К. Стеценка, С. Людкевича, Л. Ревуцького, Б. Лятошинського, Ю. Мейтуса. Специфіка цієї традиції складалася в результаті фундаментальної спирання композиторської творчості на національні особливості українського вокального мелосу (народно-пісенні інтонації мелодіiі) і музичну мову західноєвропейської професійної музики класико-романтичного періоду. Українська пісня і романс як провідні камерно-вокальні жанри у творчості професійних композиторів до початку XX століття виробили самобутній і стійкий комплекс музично-виразних засобів, витоки якого були закладені українським солоспівом ще в середині XIX ст. тим жанром, що повною мірою втілював національний варіант мистецтва загальноєвропейського камерного співу і зосередив у своїй музичній виразності особливості національного образу світу. Серед основних стильових прикмет солоспіва музикознавці зазвичай називають особливий мелодизм вокальної партії, що йде від народно-пісенної традиції, та розвиненість інструментального супроводу, який виступає рівноправним щодо вокальної лінії носієм музично-художнього сенсу.

Вже у XX столітті ці прикмети стали провідними і для багатьох зразків романсів та пісень українських композиторів, для яких актуальними виявилися і стильові пошуки такого жанру вокальної музики, як «вірші з музикою», для якого показовим $€$ принцип діалогічності вокальної та фортепіанної партій в створенні художньої виразності, що дозволяє визначати його як «вокально-фортепіанний дует» [5, с. 90-91]. Саме в руслі цих композиторських пошуків зростало значення фортепіанного звучання, яке набуло певної рівноправності в музично-художньої цілісності камерно-вокальних опусів. I в цьому ж руслі відбувалося інтонаційне збагачення вокальної мелодики як основного елементу музичної виразності камерних жанрів вокальної лірики, що проявилося в активному зверненні композиторів до мелодекламаційного стилю (А. Аренський, В. Ребіков та ін.), який є притаманним і вокальним творам В. Косенка, які зазвичай розцінюють як приклади українського солоспіва [1].

Дослідники романсів та пісень В. Косенка зазначають, що найсильніший вплив на індивідуальний стиль українського композитора надали традиції російської камерно-вокальної лірики, представлені перш за все іменами П. Чайковського 
і С. Рахманінова [3]. Деякі музикознавці в цьому вбачають важливий стильовий аспект, пов'язаний із модерною естетикою музичних творів російських композиторів [2, с. 141]. I. Вавренчук визначає цей вплив на «різних «поверхах» творчого методу Косенка: від вибору тематики до конкретних засобів іiі музичного втілення (колористичної гармонії, певних інтонаційних моделей, багатих фактурних рішень, засобів формотворення...» [2, с. 141].

О. Жукова, узагальнюючи спостереження відомих українських дослідників над музичним стилем вокальних творів В. Косенка, наводить цілу низку їхніх стильових рис: лірична, емоційна, яскрава мелодика вокальної партії, в якій присутні риси слов'янського мелосу; переважно чітка метрична структура; важлива роль фортепіанної партії, яка характеризується яскравими образотворчими й технічними можливостями, піаністичними прийомами, фактурними знахідками; романтична та складна гармонія, яка є одним із найважливіших засобів втілення змісту тексту в музиці; використання переважно класичних форм [4, с. 139], безпосередня спадкоємність цих рис від стильових принципів російської камерно-вокальної класики, яка є найважливішим етапом еволюції жанрової традиції європейської вокальної лірики і унікальним самобутнім явищем національної музичної культури.

Аналогії із С. Рахманіновим зумовлені ще й тим фактом, що обидва композитора були яскравими представниками фортепіанного виконавства свого часу, які досконало володіли своїм інструментом і тому повною мірою використовували його виразний потенціал. Значення фортепіанної партії як суттєвого чинника художнього сенсу камерно-вокального твору, формувалося у творчості В. Косенка в результаті тонкої і глибокої взаємодії композиторського та виконавського мислення, що було зумовлено «творчим тандемом композитора-акомпаніатора з «його» співаками» (за висловом О. Антонюк [1, с. 148]). Як відомо, В. Косенко щільно співпрацював як концертмейстер із відомими українськими вокалістами, які часто виконували його пісні і романси (3. Гайдай, М. Голинський, О. Благовидова, М. Литвиненко-Вольгемут, І. Паторжинський та ін.). Ця співпраця суттєво сприяла розвитку українського камерно-вокального виконавства і формуванню його професійних основ. До того ж музично-естетичні ідеали композитора щодо камерного виконавства були сфор- 
мовані також під безпосереднім впливом рахманіновського таланту: відомо, що ще в студентські роки вокальна майстерність Н. Кошиць (яка була видатною виконавицею романсів С. Рахманінова) справила колосальне враження на В. Косенка і заклала основи його ідеалу камерного співу.

Індивідуально-композиторське розуміння художньої природи камерної вокальної лірики у В. Косенка виражається, перш за все, на рівні експресії музичного висловлювання, який самі виконавці часто характеризують як емоційно-схвильований [1, с. 156], що відповідає як національним традиціям вокальної лірики (солоспів), так і класичним зразкам європейської вокальної мініатюри епохи музичного романтизму. Цей рівень зумовлений композиторським вибором поетичних текстів, які відображають різноманітність почуттів і емоцій, лірику авторського висловлення віршів М. Лермонтова та О. Пушкіна, О. Апухтіна, Ф. Тютчева, К. Бальмонта, В. Лихачова, В. Стражева, П. Тичини, О. Блока та інших поетів.

Що стосується безпосередньо музично-стилістичного комплексу, то він складається з органічної взаємодії вокальної та фортепіанної виразності, які доповнюють один одного і покликані втілити емоційні нюанси поетичного тексту, смислові відтінки переживань і почуттів ліричного героя. I тут величезного значення набуває й сама фортепіанна фактура, яка представлена надзвичайно різноманітно в романсах В. Косенка і реалізує колосальний виразний потенціал інструменту, виходячи за рамки його акомпануючої функції. Так, фортепіанна фактура може бути гранично прозорою і виступати як підтримка вокаліста («Я чекав тебе») або ж, навпаки, бути надзвичайно насиченою i «договорювати» психологічний сенс вербального тексту («Вони стояли мовчки»). Особливо яскраво звучить фортепіано в тих романсах, вокальна партія яких відрізняється мелодизмом, що становить основу виразності: в цих випадках рельєфна фортепіанна фактура, надзвичайно складна у своїх нюансах і щільності, і виступаючи тембральним і фактурним контрастом до вокальної лініі, виконує функцію «ущільнення» музичного сенсу і змісту («Соловей і ружа», «Говори, говори», «Вітер перелітний» та ін.). Також позначимо й колористичний сенс фортепіанної фактури («Соловей і ружа»). Однак стилістику вокальної мелодики В. Косенка становить переважно мовленнєво-декламаційна інтонація, яка, власне, і утворює особливу експре- 
сію вокальної партії, розвинена фортепіанна фактура покликана «укрупнити» виразний сенс вокально-фортепіанного дуету («Сумно мені», «Я ждав тебе», «Вечірня пісня», «Крук до крука» та ін.). Тому можна стверджувати, що в основу виразної ідеї камерно-вокальних творів В. Косенка покладено принцип діалогічності, що регулює співвідношення елементів вокальної та фортепіанної інтонації, покликаної відтворити внутрішній сенс поетичності тексту.

Тенденція підвищення значущості фортепіано в камерно-вокальних жанрах спостерігається в європейській композиторській творчості на межі XIX-XX ст. як у західноєвропейській музиці (у вокальних циклах Г. Вольфа, наприклад), так і в російській (П. Чайковський та С. Рахманінов насамперед).

Деякі прийоми розвитку і побудови музичної композиції в романсах В. Косенка, безумовно, вторинні щодо камерно-вокальної стилістики цих видатних представників музичного мистецтва. До таких слід зарахувати розбіжність вокальних i фортепіанних кульмінацій, поступове ущільнення фактури, використанням поліритмії. Однією з характерних особливостей камерної вокальної музики В. Косенка є яскравий мелодизм, значною мірою зумовлений гармонійним мисленням композитора. Це визначає особливості фортепіанної фактури його романсів, яка насичена самостійними голосами, які то є мелодією, то зникають у густій звуковій тканині.

У романсах українського композитора широко представлений тип концертно-віртуозної фортепіанної фактури, поряд із прозорим камерним викладом: це вимагає від піаніста виняткової звукової майстерності та чутливості до ритмічних (особливо - до використання tempo rubato), динамічних і поліфонічних деталей музичної тканини, а також до реєстрових і гармонійних фарб.

Вокальному стилю В. Косенка притаманне поєднання пластичної кантилени із завжди психологічно виправданою декламацією. I тут більш за все відчутний вплив С. Рахманінова: якщо в романсах П. Чайковського декламаційність часто пов'язана з кульмінаційними точками в романсах, то у С. Рахманінова саме 3 експресії декламаційної інтонації починається мелодійна лінія. Саме такий початковий імпульс як би «згортає» в собі подальшу драматичну гостроту музичної виразності, «вибуховість» кульмінацій, в яких розкрива- 
ється внутрішня психологічна колізія, головна думка твору. Найбільш яскравим засобом досягнення емоційного змісту романсу $є$ використання контрастної динаміки. Не менш типові для вокальної лірики «тихі» кульмінації», які при всій зовнішній стриманості мають величезну емоційну напруженість, бо виражають найпотаємніші думки і почутті автора.

Важливе значення В. Косенко надає постлюдіям, які відіграють завершальну роль у романсі, доводячи музичний розвиток до логічного кінця і доводячи до слухача «голос від автора». Цей прийом, як відомо, широко представлений у творах С. Рахманінова і становить яскравий атрибут індивідуального стилю російського композитора.

Висновки. Таким чином, стилістика романсів В. Косенка вибудовується за принципом успадкування і творчої інтерпретації класичних жанрових канонів європейської камерно-вокальної лірики. Індивідуально-композиторське трактування жанрової традиціі пов’язане переважно 3 ідеєю збагачення «романтичного духу» малої вокальної форми мелодійною виразністю, властивою українському солоспіву. Також суттєвою для В. Косенка виявляється спадкоємність від традицій російської камерно-вокальної лірики, зокрема від стилістики романсів С. Рахманінова, яка надає творам українського композитора традиціоналістські стильові характеристики. Це дає змогу розглядати камерно-вокальну спадщину В. Косенка та індивідуально-стильові орієнтири українського композитора як їх «охоронну» функцію, що спрямована на збереження i зміцнення базових жанрових принципів і жанрового стилю камерно-вокальної лірики в умовах активного поновлення музично-естетичних канонів на межі XIX-XX ст.

\section{СПИСОК ЛІТЕРАТУРИ}

1. Антонюк В. Вокальна лірика В. Косенка та формування української школи камерного співу. Науковий вісник Національної музичної академії України імені П.І. Чайковського. 2016. Вип. 115. С. 146-162.

2. Вавренчук І. Сецесійні акценти у вокальній ліриці В. Косенка. Наукові записки. Серія: Мистецтвознавство. 2012. № 3. С. 140-146.

3. Грінченко М.О. Вибране. Київ, 1959. 529 с.

4. Жукова О. Стилістичні особливості романсової творчості В. Косенка на прикладі романсу «Ветер перелётный» Ор. 1 № 4. Київське музикознавство. Вип. 56. С. 136-145.

5. Ніколаєва Л. До проблеми жанрового визначення творів для голосу з фортепіано. Музична украӥністика: сучасний вимір. 2008. Вип. 2. С. 83-92. 
6. Олійник О. Фортепіанна творчість В.С. Косенка. Київ : Наукова думка, 1977. 150 с.

7. Сохор А. Теория музыкальных жанров: задачи и перспективы. Вопросы социологии и эстетики музыки: статьи и исследования. 1983. Вып. 3. С. 129-142.

\section{REFERENCES}

1. Antonyuk, V. (2016). Vocal lyrics of V. Kosenko and the formation of the Ukrainian school of chamber singing. Scientific Bulletin of the Tchaikovsky National Academy of Music of Ukraine. Vol. 115. [in Ukrainian].

2. Vavrenchuk, I. (2012). Secession accents in V. Kosenko's vocal lyrics. Proceedings. Series: Art History. № 3. [in Ukrainian].

3. Grinchenko, M. (1959). Selected works. Kyiv: State Publishing House of Fine Arts and Musical Literature of the Ukrainian SSR [in Ukrainian].

4. Zhukova, O. (2017). Stylistic features of V. Kosenko's romance on the example of the romance "Flying Wind" Or. 1 № 4. Kyiv musicology. Vol. 56. Kyiv: Kyiv R. Glier Institute of Music [in Ukrainian].

5. Nikolaeva, L. (2008). To the problem of genre definition of works for voice with piano. Musical Ukrainian Studies: Modern Dimension. Vol. 2. [in Ukrainian].

6. Oliynyk, O. (1977). Piano works by V. Kosenko. Kiev: Scientific opinion [in Ukrainian].

7. Sohor, A. (1983). Theory of musical genres: tasks and prospects. Questions of sociology and aesthetics of music: articles and research. Vol. 3. [in Russian]. 